\title{
MODIFICATION OF ALKYL ESTERS \\ OF 4-AMIN OBEN ZENETHIOSULFONIC ACID BY S-TRIAZINE FRAGMENT AND INVESTIGATION OF THEIR GROWTH-REGULATIVE ACTIVITY
}

\author{
Sofiya Vasylyuk ${ }^{1}$, Olena Komarovska-Porokhnyavets ${ }^{1}$, Volodymyr Novikov ${ }^{1}$, \\ Vira Lubenets ${ }^{1, *}$
}

https://doi.org/10.23939/chcht12.01.024

\begin{abstract}
The acylation of aminogroup of alkyl S-esters 4-aminobenzenthiosulfoacid with cyanurchloride was investigated. Series of esters with triazine fragment were synthesized and characterized by elemental analysis, ${ }^{1} \mathrm{H}$ NMR and IR spectroscopy. The growth-regulative activity of the synthesized compounds was researched. Some appropriate effect of thiosulfoesters structure upon their growth-regulative activity was determined.
\end{abstract}

Keywords: thiosulfoacid derivatives, thiosulfoesters, s-triazine, growth-regulative activity.

\section{Introduction}

The application of plant growth regulators in agriculture is an important factor in improving the quality and yield of crop production. Most functions performed in one way or another are aimed at plant protection. The use of growth regulators allows purposefully to regulate the most important processes of plant growth and development to prevent grains from falling flat, to accelerate ripening and forming fruits, to interrupt resting phases of seeds, and to prevent the fruit loss.

In addition, growth regulators increase plants resistance to adverse natural or anthropogenic factors as critical temperature differences, moisture deficit, phytotoxicity of pesticides, pests and diseases of fungal, bacterial and viral origin.

Today, the following growth-regulating drugs as Nitrozyme, Maxicrop and Sea Magic are used in agriculture in which active substances are natural (endogenous) compounds, phytohormones in particular. Based on the results of researches on endogenous growth

\footnotetext{
${ }^{1}$ Lviv National Polytechnic University, 12, S. Bandery St., 79013 Lviv, Ukraine vlubenets@gmail.com

(C) Vasylyuk S., Komarovska-Porokhnyavets O., Novikov V., Lubenets V., 2018
}

regulators and their participation in metabolism, synthetic (exogenous) growth regulators were made, such as Ivin, Poteitin, and Lucis, which are also widely used in agriculture.

s-Triazine derivatives are of interest in terms of finding new growth regulators [1-3]. 1,3,5-Triazines or s-triazines have been known for over 100 years. Their derivatives are used as herbicides, plant protection products, drugs, reagents for condensation in peptide synthesis, dye synthesis, at modification of polysaccharides, etc. [3-8]. Not so long ago, substituted triazine was isolated from algae, and characterized by a number of physical chemical methods [9].

Derivatives of thiosulfonic acids are no less of interest in this aspect of research. In particular, thiosulfoesters exhibiting high growth-stimulating activity in relation to crops are quite known [10-13]. Aforementioned compounds are getting more of interest due to the fact that thiosulfoesters are structural analogues of natural antibacterial substances [14-16].

It is known that synthetic esters of thiosulfoacids possess the biological activity, which often exceeds the efficiency of natural analogues [17]. Quite a few of them are offered as medicines, preservatives of fruit and vegetables, effective remedies for plant protection, growth regulators, biocidal additives, insecticides and radioprotector. [17-21]. In addition, thiosulfoacid esters are effective sulfenilating and sulfonylating reagents in organic synthesis, and also valuable objects for solving complex issues of molecular biology and biochemistry $[17,22,23]$.

Among thiosulfoacid derivatives with a wide range of biological activity at relatively low toxicity (LD50 = $=2500 \mathrm{mg} / \mathrm{kg}$ ), alkyl S-esters of 4-aminobenzenethiosulfoacids are pointed out [17, 21].

Therefore, in order to search for new promising growth regulators and making comparative researches on determination of "structure and biological activity" 
regularities of thiosulfonates, it is certainly important and interesting to synthesize and research growth-regulative properties of the above-mentioned thiosulfoesters modified by the s-triazine moiety because they are the closest structural analogues of alkyl S-esters of 4- aminobenzenethiosulfoacids.

\section{Experimental}

\subsection{General Experimental Details}

All melting points were determined in open capillary tubes and were uncorrected. $\mathrm{H}^{1} \mathrm{NMR}$ spectra were recorded on a Bruker Avance DRX-500 spectrometer $(500 \mathrm{MHz}$ ) in DMSO-d6, the chemical shifts were measured relative to tetramethylsilane. IR spectra were recorded on SPECORD M80 spectrophotometer in tablets with $\mathrm{KBr}$. Monitoring of the reactions and individuality of compounds were performed by TLC method on Silufol UV254 plates.

\subsection{Synthesis of Main Compounds}

Alkyl esters of 4-aminobenzenethiosulfoacid 1a-c. Methods of obtaining the compound and its characteristics are presented in the previous work [24].

General procedure of aminogroup acylation of alkyl S-esters 4-aminobenzenthiosulfoacid $\mathbf{l a - c}$ with cyanurchloride. The pyridine $(0.0027 \mathrm{~mol})$ was added to the cooled $(268-273 \mathrm{~K})$ solution $(0.0027 \mathrm{~mol})$ of cyanuric chloride in acetone $(10 \mathrm{ml})$ under intensive stirring. The mixture was stirred for $10 \mathrm{~min}$ and solution $(0.0027 \mathrm{~mol})$ of appropriate alkyl S-ester of 4-aminobenzenthiosulfoacid in acetone was gradually added at the temperature not higher than $273 \mathrm{~K}$. After $0.5 \mathrm{~h}$ the reaction mass was filtered, and the filtrate was poured onto ice. The resulting precipitate was filtered off and recrystallized from methanol.

S-methyl 4-[(4,6-dichloro-1,3,5-triazin-2-yl)amino] benzenesulfonothioate $2 a$. Yield $67.5 \%$, mp: 499-500 K; IR $\left(\mathrm{KBr}, \mathrm{cm}^{-1}\right)^{2}:$ 688-704 $4^{\beta * * *}, 808^{\gamma * * *}, 1016-1080 * *$, $1416-1548^{\gamma}$ (triazine ring), 848, 1168, 1256, $1292(\mathrm{C}-\mathrm{Cl})$, $1136_{\gamma_{\mathrm{s}}}, 1328$ yas $\left(\mathrm{SO}_{2}\right), 1584,1598\left(\mathrm{C}=\mathrm{C}_{\mathrm{ar}}\right), 1616(\mathrm{C}=\mathrm{N})$, $3304(\mathrm{NH}),{ }^{1} \mathrm{H}$ NMR (500 MHz, DMSO-d $)$ : $\delta 2.02 \mathrm{~s}(3 \mathrm{H}$, $\left.\mathrm{CH}_{3}\right), 7.28 \mathrm{~d}(2 \mathrm{H}, \mathrm{J}=7.8 \mathrm{~Hz}, \mathrm{Ar}-\mathrm{H}), 7.88 \mathrm{~d}(2 \mathrm{H}, \mathrm{J}=7.8 \mathrm{~Hz}$, Ar-H), $8.1 \mathrm{~s}(1 \mathrm{H}, \mathrm{NH}), \mathrm{MS}(\mathrm{EI}) \mathrm{m} / z$ 352.43[M+1]. Anal. calcd for $\mathrm{C}_{10} \mathrm{H}_{8} \mathrm{Cl}_{2} \mathrm{~N}_{4} \mathrm{O}_{2} \mathrm{~S}_{2}$ : C, 34.19; H, 2.29; Cl, 20.19; N, 15.95; S, 18.25; found: C, 33.85; H, 2.42; Cl, 19.84; N, $15.62 ; \mathrm{S}, 17.98$.

\footnotetext{
** "Breathing" oscillations of the ring.

$* * * \beta$ - plane deformation oscillations of the ring; $\gamma$-off-planar deformation oscillations of the ring;
}

S-ethyl 4-[(4,6-dichloro-1,3,5-triazin-2-yl)amino] benzenesulfonothioate $2 \boldsymbol{b}$. Yield 75\%, mp: 497-498 K; IR $\left(\mathrm{KBr}, \mathrm{cm}^{-1}\right): 688-720^{\beta} * * *, 810^{\gamma * * *}, 1016-1100 * *, 1424-$ $1548^{\gamma}$ (triazine ring), 848, 1156, 1270, $1296(\mathrm{C}-\mathrm{Cl})$, $1136_{\gamma \mathrm{s}}, 1320 \gamma_{\mathrm{as}}\left(\mathrm{SO}_{2}\right), 1580,1600\left(\mathrm{C}=\mathrm{C}_{\mathrm{ar}}\right), 1612(\mathrm{C}=\mathrm{N})$, $3304(\mathrm{NH}),{ }^{1} \mathrm{H}$ NMR $\left(500 \mathrm{MHz}, \mathrm{DMSO}_{-} \mathrm{d}_{6}\right): \delta 1.4 \mathrm{t}(3 \mathrm{H}, \mathrm{J}$ $\left.=7.4 \mathrm{~Hz}, \mathrm{CH}_{3}\right), 3.1 \mathrm{q}\left(2 \mathrm{H}, \mathrm{J}=7.3 \mathrm{~Hz}, \mathrm{CH}_{2}\right), 7.2 \mathrm{~d}(2 \mathrm{H}$, $\mathrm{J}=7.8 \mathrm{~Hz}, \mathrm{Ar}-\mathrm{H}), 7.9 \mathrm{~d}(2 \mathrm{H}, \mathrm{J}=7.8 \mathrm{~Hz}, \mathrm{Ar}-\mathrm{H}), 8.12 \mathrm{~s}(1 \mathrm{H}$, $\mathrm{NH}$, MS (EI) $\mathrm{m} / \mathrm{z} 366.33[\mathrm{M}+1]$. Anal. calcd for $\mathrm{C}_{11} \mathrm{H}_{10} \mathrm{Cl}_{2} \mathrm{~N}_{4} \mathrm{O}_{2} \mathrm{~S}_{2}$ : C, 36.17; H, 2.76; Cl, 19.41; N, 15.34; S, 17.56; found: C, 35.86; H, 2.93; Cl, 19.10; N, 15.11; S, 17.95 .

S-propyl 4-[(4,6-dichloro-1,3,5-triazin-2-yl)amino] benzenesulfonothioate $2 c$. Yield $61.8 \%$, mp: 455-456 K; IR $\left(\mathrm{KBr}, \mathrm{cm}^{-1}\right): 700-720^{\beta_{* * *}}, 806^{\gamma_{* * *}, 1024-1100 * *}$, $1420-1550^{\gamma}$ (triazine ring), 848, 1162, 1260, $1296(\mathrm{C}-\mathrm{Cl})$, $1120_{\gamma}, 1304$ ras $\left(\mathrm{SO}_{2}\right), 1588,1600 \quad\left(\mathrm{C}=\mathrm{C}_{\mathrm{ar}}\right), 1612(\mathrm{C}=\mathrm{N})$, $3314(\mathrm{NH}),{ }^{1} \mathrm{H}$ NMR $\left(500 \mathrm{MHz}, \mathrm{DMSO}_{-} \mathrm{d}_{6}\right): \delta 1.2 \mathrm{t}(3 \mathrm{H}, \mathrm{J}$ $\left.=6.8 \mathrm{~Hz}, \mathrm{CH}_{3}\right), 1.89 \mathrm{~m}\left(2 \mathrm{H}, \mathrm{CH}_{2}-\mathrm{CH}_{3}\right), 2.7 \mathrm{t}(2 \mathrm{H}, \mathrm{J}=6.3$ $\left.\mathrm{Hz}, \mathrm{S}-\mathrm{CH}_{2}\right), 6.6 \mathrm{~d}(2 \mathrm{H}, \mathrm{J}=7.8 \mathrm{~Hz}, \mathrm{Ar}-\mathrm{H}), 7.8 \mathrm{~d}(2 \mathrm{H}, \mathrm{J}=7.9$ $\mathrm{Hz}, \mathrm{Ar}-\mathrm{H}), 8.06 \mathrm{~s}(1 \mathrm{H}, \mathrm{NH}), \mathrm{MS}(\mathrm{EI}) \mathrm{m} / z 379.29$ [M+1]. Anal. calcd for $\mathrm{C}_{12} \mathrm{H}_{12} \mathrm{Cl}_{2} \mathrm{~N}_{4} \mathrm{O}_{2} \mathrm{~S}_{2}$ : C, 38.00; $\mathrm{H}, 3.19 ; \mathrm{Cl}$, 18.69; N, 14.77; S, 16.91; found: C, 37.72; H, 3.43; Cl, $18.36 ; \mathrm{N}, 14.39 ; \mathrm{S}, 16.63$.

\subsection{Biology}

\subsubsection{Grow-regulating activity research}

Grow-regulating activity of the researched compound is studied according to the standard methods modified by T. Sergeyeva [25]. The experiment is carried out on agar medium of the following composition $(\mathrm{g} / \mathrm{l})$ : $\mathrm{MgSO} 4 \cdot 7 \mathrm{H}_{2} \mathrm{O}-1 ; \mathrm{K}_{2} \mathrm{HPO}_{4}-1 ; \mathrm{FeSO} 4 \cdot 7 \mathrm{H}_{2} \mathrm{O}-0.02$; agar -8 . Some amount of compound solution is added to medium which is put into Petri plates.

Monocotyledons (oats) and dicotyledons (cress) seeds are used in the test. Seed samples are couched on agar medium for 3 days in thermostat at $295 \mathrm{~K}$ with further germinants growing for 4 days in the dry box by artificial light at 292-293 K.

Seed germination and linear size of plant components are defined at the end of the test. The results are presented in percentage concerning control samples. Forcing is defined at the index exceeding $100 \%$ and growth inhibition is defined at the index under $100 \%$. Tests are thrice-repeated.

\section{Results and Discussion}

\subsection{Chemistry}

Despite detailed study and widespread use of s-triazines in organic synthesis and particularly the use of 
cyanurchloride just as a reagent for thiosulfoesters [26], there is quite not enough information on thiosulfonate 1,3,5-triazine. Obtaining of thiosulfoesters with a triazine fragment by the heterylation of salts of aliphatic thiosulfonic acids with cyanurchloride [27] is a wellknown fact.

Taking into account the synthetic capabilities of mono- and di-substituted derivatives of 1,3,5-triazine, we investigated the interaction of alkyl S-esters of 4-aminobenzenthiosulfoacid with cyanurchloride in aprotonic and protonic solvents in the conditions of nucleophilic catalysis in the presence of tertiary amines.

Within the temperature range of $268-273 \mathrm{~K}$, in the presence of acetone, pyridine forms an intermediate adduct with cyanurchloride that precipitates. The newly formed adduct easily interacts with an acetone solution of alkyl S-esters of 4-aminobenzenthiosulfoacid. The monosubstitution of chlorine in cyanurchloride when it interacts with thiosulfoesters 1a-c in the above conditions, results in 60-75\% yield of S-alkyl 4-[(4,6-dichloro-1,3,5triazin-2-yl)amino]benzenesulfonothioates $\mathbf{2 a - c .}$

Acylation of ethyl S-esters of 4-aminobenzenthiosulfoacid 1b with cyanurchloride occurs at 273-278 K in a non-polar solvent (benzene) in the presence of triethylamine with an equimolar ratio of reagents followed bythe formation of monosubstitution product $\mathbf{2 b}$ with a significantly lower yield (25\%).

\subsection{G rowth-Regulative Activity}

In order to find new growth regulators for plants that are competitive with commercial drugs, the growth regulating activity of synthesized thiosulfoester derivatives of s-triazine $\mathbf{2 a - c}$ has been researched (Table).

The results of the researches indicate that at the concentration of $100 \mathrm{mg} / \mathrm{l}$, S-methyl 4-[(4,6-dichloro1,3,5-triazin-2-yl)amino]benzenesulfonothioate $\mathbf{2 a}$ tends to stimulate oat root growth by $12 \%$ and stem growth by $2 \%$. The sprouting of oat at the same concentration as compared to the control is higher by $37 \%$. At the concentration of $100 \mathrm{mg} / \mathrm{l}$, compound $\mathbf{2 a}$ activates the cress root growth by $41 \%$. The sprouting of the cress and the control is the same. With the decrease in the concentration of the compound $\mathbf{2 a}$ in the medium, there is stimulation of both cress root growth (at $1 \mathrm{mg} / \mathrm{l}$ by $55 \%$ ), oat stem and root growth (at $1 \mathrm{mg} / \mathrm{l}$ by $30 \%$ ). Consequently, thiosulfoester $\mathbf{2 a}$ contributes to the oat and cress growth mostly in all researched concentrations in relation to the control. It is quite typical that the growth of plants increases while the concentration decreases.

S-ethyl 4-[(4,6-dichloro-1,3,5-triazin-2-yl)amino] benzenesulfonothioate $\mathbf{2 b}$ stimulates oat stem and roots, as well as cress growth to some extent as well. At the concentration of $100 \mathrm{mg} / \mathrm{l}$, compound $\mathbf{2 b}$ contributes to the oat stem and roots growth by $18-19 \%$, and at the concentration of $1 \mathrm{mg} / \mathrm{l}$ - by 58 and $74 \%$, respectively. The sprouting of oat exceeds the sprouting in the control sample by $37 \%$ at the concentration of $100 \mathrm{mg} / \mathrm{l}$. In the amount of $100 \mathrm{mg} / \mathrm{l}$ thiosulfoester $\mathbf{2 b}$ stimulates the cress root growth by $2 \%$ (sprouting to the control is $40 \%$ lower), and at the concentration of $1 \mathrm{mg} / \mathrm{l}$ - by $10 \%$ (sprouting is $24 \%$ lower). The sprouting of the cress is lower by 40-24\% compared to the control.

As can be seen from Table, at the concentration of $100 \mathrm{mg} / \mathrm{l}, \quad$ S-propyl 4-[(4,6-dichloro-1,3,5-triazin-2-yl) amino] benzenesulfonothioate $\mathbf{2 c}$ is a stimulating factor of oat growth (i.e. root and stem). At the concentration of $100 \mathrm{mg} / \mathrm{l}$, the oat root and stem growth is higher by 20 and $10 \%$, respectively, while the sprouting is $21 \%$ higher than in the control. Mostly, ester 2c contributes to the oat growth with a decrease in concentration (at the concentration of $1 \mathrm{mg} / \mathrm{l}$ the root and stem growth is higher by $54-56 \%$.

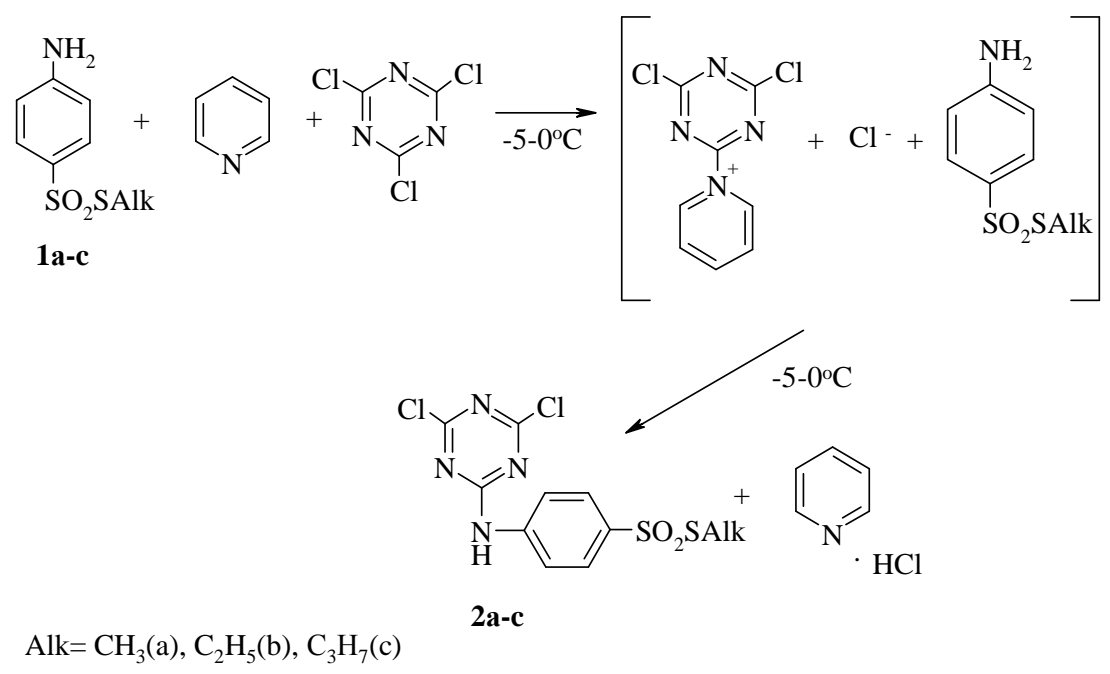


Growth-regulative activity of thiosulfoesters

\begin{tabular}{|c|c|c|c|c|c|c|}
\hline \multirow{3}{*}{ Compound } & \multirow{3}{*}{$\begin{array}{l}\text { OD } \\
\Xi \\
\tilde{\Xi} \\
\tilde{0}\end{array}$} & \multicolumn{2}{|c|}{$\begin{array}{c}\text { Growth-regulative activity, } \\
\% \text { to control }\end{array}$} & \multirow{3}{*}{ 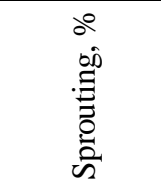 } & $\begin{array}{l}\text { Growth-regulative } \\
\text { activity, }\end{array}$ & \multirow{3}{*}{ 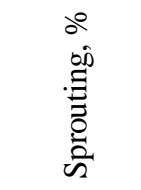 } \\
\hline & & \multicolumn{2}{|c|}{ oat } & & cress & \\
\hline & & root & stem & & root & \\
\hline 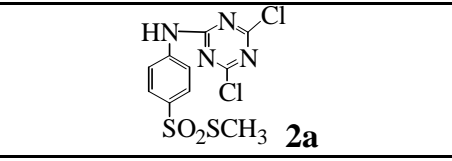 & $\begin{array}{c}100 \\
10 \\
1\end{array}$ & $\begin{array}{l}112.0 \pm 2.0 \\
125.1 \pm 1.6 \\
130.0 \pm 1.9\end{array}$ & $\begin{array}{l}102.0 \pm 1.5 \\
128.3 \pm 2.0 \\
128.0 \pm 2.3\end{array}$ & $\begin{array}{c}137.5 \pm 1.9 \\
84.2 \pm 1.1 \\
147.4 \pm 1.5\end{array}$ & $\begin{array}{l}141.1 \pm 2.4 \\
145.0 \pm 1.9 \\
155.5 \pm 1.8\end{array}$ & $\begin{array}{c}100.2 \pm 1.2 \\
88.0 \pm 1.1 \\
104.0 \pm 1.6\end{array}$ \\
\hline $\mathrm{SO}_{2} \mathrm{SC}_{2} \mathrm{H}_{5} \quad \mathbf{2 b}$ & $\begin{array}{c}100 \\
10 \\
1\end{array}$ & $\begin{array}{l}118.0 \pm 1.5 \\
154.4 \pm 1.3 \\
158.3 \pm 1.2\end{array}$ & $\begin{array}{l}119.2 \pm 1.5 \\
159.0 \pm 1.8 \\
174.2 \pm 2.8\end{array}$ & $\begin{array}{c}137.0 \pm .1 .0 \\
121.0 \pm 1.7 \\
168.4 \pm 2.2\end{array}$ & $\begin{array}{l}102.0 \pm 1.1 \\
105.0 \pm 0.9 \\
110.4 \pm 1.5\end{array}$ & $\begin{array}{l}60.4 \pm 1.1 \\
72.3 \pm 1.0 \\
76.6 \pm 1.4\end{array}$ \\
\hline $\mathrm{SO}_{2} \mathrm{SC}_{3} \mathrm{H}_{7} \mathbf{2 c}$ & $\begin{array}{c}100 \\
10 \\
1\end{array}$ & $\begin{array}{l}120.0 \pm 1.7 \\
130.3 \pm 0.9 \\
156.0 \pm 1.0\end{array}$ & $\begin{array}{l}110.4 \pm 1.1 \\
121.0 \pm 1.7 \\
154.0 \pm 1.9\end{array}$ & $\begin{array}{l}121.0 \pm 2.4 \\
111.3 \pm 1.7 \\
126.0 \pm 1.9\end{array}$ & $\begin{array}{l}119.7 \pm 1.0 \\
157.3 \pm 1.9 \\
161.1 \pm 1.3\end{array}$ & $\begin{array}{c}64.8 \pm 1.1 \\
84.2 \pm 1.5 \\
108.0 \pm 1.0\end{array}$ \\
\hline$-\mathrm{SO}_{2} \mathrm{SC}_{2} \mathrm{H}_{5}$ & $\begin{array}{c}100 \\
10 \\
1\end{array}$ & $\begin{array}{c}66.0 \pm .0 .9 \\
109.0 \pm 1.1 \\
95.3 \pm 2.1\end{array}$ & $\begin{array}{c}84.3 \pm 1.1 \\
103.7 \pm 0.9 \\
95.2 \pm 1.6\end{array}$ & $\begin{array}{c}80.1 \pm 1.0 \\
96.0 \pm 1.1 \\
101.0 \pm 1.5\end{array}$ & $\begin{array}{c}80.0 \pm 0.9 \\
115.0 \pm 1.5 \\
118.2 \pm 1.2\end{array}$ & $\begin{array}{c}70.0 \pm 0.9 \\
115.0 \pm 1.1 \\
120.4 \pm 1.7\end{array}$ \\
\hline $\begin{array}{l}\text { Terpal } \\
\text { (growth-inhibition preparation) }\end{array}$ & $\begin{array}{c}100 \\
10 \\
1\end{array}$ & $\begin{array}{l}52.4 \pm 2.3 \\
76.0 \pm 1.5 \\
90.0 \pm 1.7\end{array}$ & $\begin{array}{c}83.3 \pm 2.0 \\
103.1 \pm 2.1 \\
101.0 \pm 1.1\end{array}$ & $\begin{array}{c}114.4 \pm 1.9 \\
105.0 \pm \pm 1.3 \\
117.0 \pm 2.0\end{array}$ & $\begin{array}{l}42.0 \pm 1.6 \\
59.2 \pm 0.9 \\
79.5 \pm 1.2\end{array}$ & $\begin{array}{c}102.2 \pm 2.1 \\
102.4 \pm 1.5 \\
98.0 \pm 1.4\end{array}$ \\
\hline $\begin{array}{c}\text { Ivin } \\
\text { (growth-promotional preparation) }\end{array}$ & $\begin{array}{c}100 \\
10 \\
1\end{array}$ & $\begin{array}{l}107.1 \pm 2.4 \\
108.0 \pm 1.9 \\
116.0 \pm 1.0\end{array}$ & $\begin{array}{l}107.0 \pm 0.9 \\
105.0 \pm 1.3 \\
111.4 \pm 1.6\end{array}$ & $\begin{array}{c}100.3 \pm .0 .9 \\
104.4 \pm 1.5 \\
95.0 \pm 1.4\end{array}$ & $\begin{array}{l}111.0 \pm 1.6 \\
117.0 \pm 2.1 \\
131.3 \pm 2.1\end{array}$ & $\begin{array}{l}95.4 \pm 1.1 \\
93.2 \pm 1.6 \\
95.0 \pm 1.1\end{array}$ \\
\hline
\end{tabular}

To compare the effects of the s-triazine fragment introduction into the structure of alkyl esters of 4-aminobenzenthiosulfoacid on their growth regulatory activity, the aforementioned $\mathbf{1 b}$ compound activity has been researched. At the concentration of $10 \mathrm{mg} / \mathrm{l}$ thiosulfonester $\mathbf{1 b}$ stimulates the oat root growth by $9 \%$ and the stem growth by $3 \%$. There is $16 \%$ and $34 \%$ inhibition of the stem and oat root growth, respectively, at the concentration of $100 \mathrm{mg} / \mathrm{l}$. At the concentration of $1 \mathrm{mg} / \mathrm{l}$, there is $5 \%$ inhibition of the stem and oat root growth. The sprouting of oat is lower than in the control by $20 \% \quad(100 \mathrm{mg} / \mathrm{l})$ and by $4 \% \quad(10 \mathrm{mg} / \mathrm{l})$. Ethylthiosulfonylate stimulates the growth of cress at the concentration of $10 \mathrm{mg} / \mathrm{l}$ by $15 \%$ and at the concentration of $1 \mathrm{mg} / \mathrm{l}$ by $18 \%$. The sprouting of cress is $30 \%$ lower than in the control sample at the concentration of $100 \mathrm{mg} / \mathrm{l}$, and $20 \%$ higher at the concentration of $1 \mathrm{mg} / \mathrm{l}$.

The obtained results of the researches indicate that the introduction of the s-triazine fragment into the structure of compound $\mathbf{1 b}$ contributes to its growth stimulating activity.

\section{Conclusions}

Thus, the acylation of the amino group of alkyl S-esters of 4-aminobenzenthiosulfoacid with 2,4,6- trichloro-1,3,5-triazine was investigated, and it was determined that in the polar aprotonic solvent in the presence of organic bases at low temperatures of 273-278 K, the target S-alkyl 4-[(4,6-dichloro-1,3,5triazin-2-yl)amino]benzenesulfonothioates 2a-c can be obtained with the yield of $60-75 \%$.

All the researched compounds exhibit a stimulating effect on the growth of both oat stem and root and the cress root, and it is higher compared to the well-known growth-stimulating drug Ivin.

In addition, compounds 2a-c are of a following typical regularity: with a decrease in the concentration of the substance there is an increase in the growth of the oat stem and root and of the cress root. That is, the greatest effect on plant growth is typical of low concentrations $(1 \mathrm{mg} / \mathrm{l})$.

The following compounds are of the best stimulating activity: S-ethyl 4-[(4,6-dichloro-1,3,5-triazin2-yl)amino]benzenesulfonothioate $\mathbf{2} \mathbf{b}$ at the concentration of $1 \mathrm{mg} / \mathrm{l}$; S-propyl 4-[ 4,6-dichloro-1,3,5-triazin-2yl)amino] benzenesulfonothioate $\mathbf{2 c}$ at the concentration of $1 \mathrm{mg} / \mathrm{l}$ - relative to the cress.

\section{References}

[1] Mykhaylichenko S., Chesnyuk A., Firhanh S. et al.: Pat. RU 2230063, Publ. July 10, 2004. 
[2] Kvak S., Tretyakova O., Kotlyarov N. et al.: Pat. RU 2091375 , Publ. Sept. 27, 1997.

[3] Mel'nikov N.: Pestitsidy. Khimiya, Tekhnologiya i Primeneniye. Khimiya, Moskva 1987.

[4] Saczewski F., Bulakowska A., Bednarski P., Grunert R.: Eur. J. Med. Chem., 2006, 41, 219.

https://doi.org/10.1016/j.ejmech.2005.10.013

[5] Polovkovych S., Karkhut A., Marintsova N. et al.: J.

Heterocyclic Chem., 2013, 50, 1419.

https://doi.org/10.1002/jhet.890

[6] Zhou Y., Sun Z., Froelich J. M., Hermann T., Wall D.: Bioorg.

Med. Chem. Lett., 2006, 16, 5451.

https://doi.org/10.1016/j.bmcl.2006.07.052

[7] Kelarev V., Koshelev V., Belov N.: Khimiya

Heterotsiklicheskikh Soyedineniy, 1994, 2, 240.

[8] Polovkovych S., Karkhut A., Marintsova N., Novikov V.:

Heteroatom Chem., 2010, 21, 392. https://doi.org/10.1002/hc.20631

[9] Su J.-Y., Xu X.-H., Zeng L.-M. et al.: Phytochemistry, 1998, 48,

583. https://doi.org/10.1016/S0031-9422(98)00015-6

[10] Lubenets V., Vasylyuk S., Baranovych D. et al.: Chem. Agric. Environ, 2007, 8, 163.

[11] Banya A., Karpenko O., Lubenets V. et al.: Biotechnologia Acta, 2015, 8, 71. https://doi.org/10.15407/biotech8.05.071

[12] Baranovych D., Lubenets V., Novikov V.: Ukr. Khim. Zh., 1999, 65, 130.

[13] Baranovych D., Komarovska O., Lubenets V., Novikov V.: Physiolohichno Aktyvni Rechovyny, 2000, 2, 33.

[14] Takada N., Watanabe N., Suenaga K. et al.: Tetrahedron Lett., 2001, 42, 6557. https://doi.org/10.1016/S0040-4039(01)01314-4

[15] Block E., Thiruvazhi M., Toscano P. et al.: J. Am. Chem. Soc., 1996, 118, 2790. https://doi.org/10.1021/ja951134t

[16] Block E., Shu-Hai Z.: J. Org. Chem., 1992, 57, 5815. https://doi.org/10.1021/jo00048a007

[17] Lubenets V.: Ukr. Khim. Zh., 2003, 69,109.

[18] Lubenets V., Vasylyuk S., Monka N. et al.: Pat. Ukr. 64412,

Publ. Nov. 10, 2011.

[19] Halenova T., Nikolaeva I., Nakonechna A. et al.: Ukr.

Biochem. J., 2015, 87, 83.
[20] Nawrot U., Zaczynska E., Czarny A. et al.: Mikologia Lekarska, 2012, 4, 143.

[21] Lubenets V., Karpenko O., Ponomarenko M. et al.: Chem. Chem. Technol., 2013, 7, 119.

[22] Shyam Pranab K., Soobin Son, Hye-Young Jang: Eur. J. Org. Chem., 2017, 34, 5025. https://doi.org/10.1002/ejoc.201700971

[23] Smith M., Hunter R., Stellenboom N. et al.: Biochim. Biophys. Acta, 2016, 1860, 1439.

https://doi.org/10.1016/j.bbagen.2016.03.032.

[24] Lubenets V., Vasylyuk S., Baranovych D., Novikov V.: Pat. Ukr. 14985, Publ. Jun 15, 2006.

[25] Sergeyeva T.: Metodika Laboratornykh Ispytaniy Herbitsidov. Zashchita rasteniy, Moskva 1963.

[26] Bandgar B., Pandit S.: J. Sulfur Chem., 2004, 25, 347. https://doi.org/10.1080/17415990412331317946

[27] Vasylyuk S., Lubenets V., Bychko YU.I., Novykov V.P.: Khimiya geterotsiklicheskikh soyedineniy, 2008, 1, 132.

Received: September 21, 2017 / Revised: October 16, 2017 / Accepted: November 30, 2017

\section{МОДИФІКАЦІЯ АЛКІЛОВИХ ЕСТЕРІВ 4-АМІНОБЕНЗЕНТІОСУЛЬФОКИСЛОТИ СИМ-ТРИАЗИНОВИМ ФРАГМЕНТОМ ТА ДОСЛІДЖЕННЯ ЇХ РІСТРЕГУЛЮВАЛЬНОЇ АКТИВНОСТІ}

Анотація. Досліджено ацилювання аміногрупи алкілових S-естерів 4-амінобензентіосульфокислоти ціанурхлоридом. Серію естерів із триазиновим фрагментом було синтезовано та охарактеризовано елементарним аналізом, ${ }^{1} \mathrm{H}$ ЯМР та ІЧ-спектроскопією. Досліджено рістрегулювальну активність синтезованих сполук. Визначено певний вплив структури тіосульфоестерів на їх рістрегулювальну активність.

Ключові слова: тіосульфокислотні похідні, тіосульфоестери, s-триазин, рістрегулювальна активність. 